\title{
Neurochemistry of appetite mechanisms
}

By D. A. Воотн, Department of Psychology, University of Birmingham, PO Box 363, Birmingham $B_{1} 2 T T$ and D. STRIBLING, Biochemistry Department, ICI Pharmaceuticals Division, Alderley Park, Macclesfield

Appetite is normally controlled to some extent by the metabolic effects of ingesting nutrients (Booth, Toates \& Platt, 1976). Some of these effects may be neurochemical. Diet can affect the production of a neurotransmitter and this mechanism might function in appetite if the transmitter can influence feeding (Fernstrom \& Wurtman, 1974). However, neurotransmitters could relate to appetite in at least two other ways, possibly quite independently. Transmitter release could affect the operation of, or even create, an appetite-controlling detector of nutrient status (Booth, 1972b). Alternatively, a transmitter in some synapses controlling feeding could happen to be relatively specific to the appetite system (Miller, 1965; Myers, 1974) and yet normally neither affect nutrient detection nor be functionally affected by diet. Barrett (1978) has reviewed work on the neurotransmitter actions of appetite-suppressant drugs. We concentrate on other causes of neurochemical variations which may be involved in the control of feeding behaviour, whether or not neurotransmitters are immediately implicated.

Two complexities should be acknowledged from the start. First, some of the neurochemistry controlling appetite may be in peripheral neurones, not brain tissue. Nerve endings from the autonomic innervation of the liver have been evidenced electron-microscopically (Tanikawa, 1968) and electrophysiologically (Niijima, 1969) and have been invoked by Russek (1963, 1970) as chemical receptors of great influence in the control of normal feeding. Secondly, many of the controls of feeding in man and other mammals appear to be learned, to a great extent early in life, although by no means exclusively so. Only after learning from experience of the after-effects of feeding do the appearances and many of the flavours and textures of nutritious foodstuffs become appetizing (Hogan, 1973; Reisbick, 1973; Booth, Stoloff \& Nicholls, 1974). Furthermore, appetite is not elicited by the food alone. The rituals, situations and times of day that have generally yielded amelioration of need, and the sensations often experienced when the individual needs nutrient and is faced with food which is then eaten, also all become part of the appetizing situation; that is, they tend to direct behaviour into eating the appropriate food in a roughly suitable amount (Bruch, 1973; Konorski, $1967 ;$ Booth, $1977 a, b)$. One implication is that the neurochemical events or other biochemical bases of appetite occur while learning is being established after an unfamiliar meal or drug; they need not be present while the resulting feeding behaviour is repeatedly observable afterwards (for examples, see Booth, 1972a; 
Simson \& Booth, I 974a). As any effect of a meal in peripheral tissue or even the brain could, if sensed, become a cue which the organism learns to use to predict functionally important changes in nutritional status, another implication is that an effect of diet on a transmitter could make it specific to the appetite system, although this is not necessarily the result, for the acquired neural coding could be spatial not chemical.

\section{APPETITES FOR AMINO ACIDS}

Rats reject a diet which is relatively or absolutely deficient in an essential amino acid. Leung, Rogers \& Harper (1968), Booth \& Simson (1971) and Zahler \& Harper (1972) have shown that, in at least some instances, the rats acquire a dislike for whatever distinctive sensory characteristics the deficient diet possesses. Some effect of absorbing the deficient amino acid mixture conditions an aversion to the correlated food cues. This could suppress intake if the aversive diet is the only one available. It also means that the rat has acquired a relative preference for other diets which are not deficient or imbalanced and will tend to select them when available.

\section{Brain mechanisms}

Leung \& Rogers (1969) reported that infusion of the deficient amino acid into the carotid vein at a rate of $4 \mathrm{mg} / \mathrm{d}$ prevented the depression of intake on an imbalanced diet (relatively deficient in either threonine or isoleucine). The same dose in the jugular vein had no effect, indicating that the amino acid imbalance acted at a site in the brain.

Brain concentrations of the limiting amino acid decrease rapidly after feeding on a diet with an amino acid deficiency. Cerebral transport competition and hepatic utilization stimulation from the excess of non-limiting amino acids in an imbalanced diet appear to amplify this effect (Peng, Tews \& Harper, 1972). It may also be seen after a single meal on an histidine-free or isoleucine-free diet (P. C. Simson \& D. A. Booth, unpublished results). Clear depressions in food intake take longer to develop than the decreases in brain free amino acid, presumably because a conditioned aversion cannot affect feeding until the second and later meals. When an histidine-free but otherwise balanced amino acid mixture is injected directly into the brain just before the rat eats an odorized protein-free diet, with some injection sites the rat shows in a later test that it has acquired an aversion to the dietary odour, relative to another odour which had been paired with injection of a balanced mixture at the same site on another day (Table I). The effective cannula sites were widely scattered through the forebrain but all penetrated the lateral ventricle or were very close to its ventral wing. Leung \& Rogers (1973) interpret the effects of brain lesions on intake and selection of amino acid imbalanced diets to indicate that ventrolateral forebrain contains chemical detector regions controlling this feeding behaviour. As our observations were based on the relative effect of the omission of $16 \mathrm{nmol}$ histidine hydrochloride, the mechanism 
Table 1. Azersion scores* in two-odour choice test after conditioning of odours by balanced and histidine-free intracranial injections $\dagger$ (D. A. Booth \& P. C. Simson, unpublished results).

Histologically identified site of injections

No injections

Anterior caudate-putamen

Hypothalamus (anterolateral and ventromedial)

Medial thalamus

Thalamus and fornix, with penetration of dorsal lateral ventricle

Ventral lateral ventricle, approached medially

Ventral lateral ventricle, approached laterally

Lateral amygdala

Ventral hippocampus

Midbrain

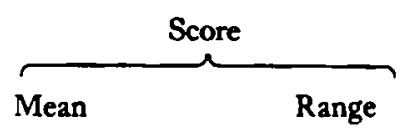

-0.44
$-2 \cdot 0$
0.3
$-3 \cdot 1$
4.17
5.07
$6.3 \ddagger$
-1.9
$-4 \cdot 2$
$-1 \cdot 3$

$\mathrm{I} \cdot 8--5 \cdot 3$

$-0.8--3.5$

$1.9--1.8$

$-0.8--5.4$

$5 \cdot 7-3 \cdot 0$

$5 \cdot 7-4 \cdot 2$

$7 \cdot 2-5 \cdot 6$

$-1 \cdot 8--2 \cdot 0$

$-1.9--6.5$

$-1 \cdot 1--1 \cdot 5$

-Intake (g) of protein-free diet with amino acid balance-paired odour minus intake (g) of same diet with histidine-free mixture-paired odour.

tInjection through 34-gauge needle (Booth, 1968) of I $\mu$ l of a solution containing $0.1 \mathrm{mg}$ amino acid mixture balanced with one dietary odour on the first day, the histidine hydrochloride $(30 \mathrm{mg} / \mathrm{ml}$ ) omitted on another day with the other odour.

$\ddagger$ Lateral ventricle groups together $(P<0.00 x)$ and one rat in each of the three groups $(P<0.04)$ differ from 'no-injections' group by $t$ tests. Each group differed from 'no-injections' group by Mann-Whitney tests $(P<0.02, n 3 ; P<0.05, n 2)$.

may be more specific than the effects of single amino acids (Wayner, Ono, DeYoung \& Barone, 1975) or balanced mixtures (Panksepp, 1972; Panksepp \& Booth, 1973). Also, if transport competition is critical in this instance, it cannot be the transport between blood and brain (cf. Lutz, Tews \& Harper, 1975). Peng \& Harper ( 1970 ) reported decreased incorporation of histidine into brain protein after feeding an histidine-imbalanced diet. However, inhibition of brain protein synthesis is difficult to substantiate in such instances (Roberts, 1974).

Simson \& Booth $\left(1974^{b}\right)$ found a considerable variety of essential amino acids whose omission caused conditioned aversion. They suggested that the detector region contains neurones whose activity depends on a peptide transmitter or protein with rapid turnover. Although unlikely here, an example is carnosine ( $\beta$ alanyl-L-histidine), a proposed transmitter in the olfactory pathway (Margolis, 1974), whose concentration can be affected by dietary histidine (Quinn \& Fisher, 1977). Neurotransmitter amines may be involved in some amino acid deficiency or imbalance anorexias or aversions, but it seems unlikely that a unitary amine effect will explain all the phenomena. Histidine omission might affect brain histamine level, as large excesses of brain histidine can increase it (Enwonwu \& Worthington, 1975; Tyfield \& Bolton, 1976). Omission of isoleucine or valine conditions aversion (Simson \& Booth, $1974^{b}$ ) and might alter competition for brain tryptophan uptake. 
Threonine omission or imbalance causes at least anorexia but has no known relation to a neurotransmitter amine or its precursor supply.

\section{Protein selection}

Control of nitrogen utilization and output is understood but the concept of control of $\mathrm{N}$ input is controversial (Harper, 1976). Nevertheless, observations of a limited extent of protein intake control subsidiary to energy intake control continue to accumulate (Leshner, Siegel \& Collier, 1972; Booth, 1974a; Musten, Peace \& Anderson, 1974; Ashley \& Anderson, 1975; Schoenfeld \& Hamilton, 1976). Booth (1974b) suggested that the conditioned aversions to diets creating amino acid deficiencies may help put a lower limit on protein intake. Critical experiments remain to be done on the hypothesis (Simson \& Booth, 1973; Noda, 1975; Harper, 1976) that ammonia toxicity enforces an upper limit on intake of protein and single amino acids, until or unless hepatic enzymes can adapt to provide a sufficient increase in urea synthesis and utilization of amino acid-carbon for energy (Das \& Waterlow, 1974). It also remains to be seen where ammonia acts on the nervous system to produce anorexia or to condition aversion, in the brain or in the liver (Russek, 1970).

Fernstrom \& Wurtman (1974) suggested that dietary influences on brain 5hydroxytrytamine $(5-\mathrm{HT})$ might in turn affect feeding behaviour. Ashley \& Anderson (1975) compared the plasma value for tryptophan:neutral amino acids with the selection of protein during long-term dietary choices. They found strong negative correlations and suggested that brain $5-\mathrm{HT}$ controlled protein selection. Equally, protein selection could affect plasma tryptophan:neutral amino acid value. Furthermore, direct manipulation of brain 5 -HT produced effects opposite to those predicted from the correlation. Presumed 5 - $\mathrm{HT}$ rise increased protein intake (Wurtman \& Wurtman, 1977). Depletion of brain 5-HT (and not of catecholamines) resulted in selection of relatively less high-protein diet (Ashley \& Anderson, 1977), although interactions between dietary unpalatabilities and general behavioural disruption remain to be excluded. Indeed, we lack any proposal as to how brain 5 -HT levels control the choice in rats of which diet to take and how much.

Studies of $\mathrm{N}$ appetites become physiologically and behaviourally unrealistic when they do not attract research support unless fashionable neurotransmitter theories are invoked. Fortunately, kwashiorkor is treated with increasing regard for the importance of learning to like those foodstuffs adequate in amino acid content which are available to the family.

\section{APPETITE FOR ENERGY}

Rats and people learn to prefer carbohydrate-rich foods to carbohydrate-dilute foods while hungry, but tend to reverse that preference when nearly satiated (Booth, I972a; Booth, Lovett \& McSherry, 1972; Booth, Lee \& McAleavey, 1976). The normal satiety signal complex, or cue for the postprandial aversion to food, 
has an intense postintestinal component after absorption of fructose or ethanol as well as after glucose absorption (Booth, 1972c; Booth \& Jarman, 1976). Together these findings indicate that the supply of readily-oxidized substrates can control the selection of foodstuffs and the amounts eaten, but the control is largely indirect, via learning to anticipate metabolic satiation. The question is what exactly is being anticipated. Dramatic changes in metabolism occur once absorption accelerates during and after a meal. Some changes begin even before eating starts: the sight or smell of food while hungry elicits insulin secretion and other preparatory reflaxes (unconditioned or conditioned). Nevertheless, there has been remarkably little success either at finding neurochemical correlates of normal feeding or at affecting feeding by manipulating brain biochemistry within a range likely to be relevant to normal appetite and satiation. The well-known cytoglucopoenic feeding, elicited by administration of insulin or 2-deoxyglucose (2DG), appears not to be mediated by the normal brain but by the liver at modest doses (Novin, VanderWeele \& Rezek, 1973; Stricker, Rowland, Saller \& Friedman, 1977) and by acute neuropathology at higher doses (Russell \& Mogenson, r975; Brandes, 1977). If cerebral detectors of glucose or other energy substrates controlling feeding were located by other means and their normal metabolic variation measured, the relevance of insulin- or 2-DG-induced feeding could be reevaluated.

\section{Brain lesions}

Release of excessive food intake, whether by destruction of glucose-dependent glia (Debons, Krimsky, From \& Cloutier, 1970) or blood vessels (Gaffyn, 1972), electrolysis (Brobeck, 1946) or knife-cuts (Sclafani, I97I), does not show that the lost cells were satiety detectors. They might merely be the route for output from such detectors elsewhere in the brain or periphery. Animals made hyperphagic to obesity by lesions in the ventromedial hypothalamus (VMH) show normal metabolic satiety (Booth, Toates et al. 1976). Probably VMH is not even a path for satiety information (Panksepp, 1971; Rabin, 1972). Rather, it has neuroendocrine functions which include restraining the conversion of nutrients into stored triglyceride. The insulin secretory responses to glucose and to unconditioned and conditioned appetizers are all abnormally great after VMH lesions (Inoue, Bray \& Mullen, 1977; Powley, 1977; Roehner, Dufour, Karakash, Le Marchand, Ruf \& Jeanrenaud, 1977). VMH lesions increase energy intake selectively over protein intake (Anderson, Leprohon \& Coscina, 1978). Extra energy storage after VMH lesions would create a secondary desatiation of energy appetite, until accumulated fat provided a background satiety which reduced daily food intake (Booth, 1978).

\section{Intracranial injections}

Occasional reports of prompt suppression of feeding by intrahypothalamic injection of glucose have proved difficult to replicate (Grossman, 1968) and may in any instance reflect sedation rather than normal satiety (Booth, I968a). A delayed suppression has been observed after injection of glucose into the VMH (Panksepp 
\& Nance, 1972; Panksepp, 1975). This could result from neuroendocrine control of peripheral fat deposition and mobilization. Glucose uptake in circumventricular parts of the brain appears to be insulin-sensitive (Rafaelson, 1961; Debons, Krimsky, From \& Cloutier, 1969; Smith, 1972; Szabo \& Szabo, 1972; Oomura, 1976). Strubbe (1973) found dose-related increases in food intake immediately after injection of anti-insulin serum above the $\mathrm{VMH}$ of the satiated rat (although signs of a dose relation appeared in pre-injection intakes). It is difficult to detect effects of circulating insulin on whole brain metabolism (Gilboe, Andrews \& Dardenne, 1970).

\section{Neurochemical correlates}

Early reports of differences between the VMH and lateral hypothalamus (LH), and between their responses to starvation or re-feeding, have been supported by Panksepp \& Reilly's ( 1975) observations on oxygen consumption by VMH and LH homogenates and on in vivo incorporation of label from peripherally-administered $\left[\mathrm{U}-{ }^{14} \mathrm{C}\right.$ ]glucose and other substrates (Panksepp, 1972, 1975). A differential retention of ${ }^{14} \mathrm{C}$ in $\mathrm{VMH}$ (possibly to the extent to be expected from differential uptake) was concentrated in lipophilic and acid-insoluble fractions (Panksepp \& Pilcher, 1973; Panksepp, 1975). Nicolaïdis, Monique \& Polonowski (1974) also reported dependence of hypothalamic lipids on nutritional status. Both workers propose that body fat is functionally represented in VMH lipid.

Pilcher, Jarman \& Booth (1974) showed that ${ }^{14} \mathrm{C}$ from a starch meal could enter rat liver and brain in less than $5 \mathrm{~min}$ after the start of the meal on an empty stomach. Under maintenance conditions on a laboratory diet fed ad lib., the stomach empties and the intestine absorbs at nearly constant rate for most of the period after a meal (J. C. Newman \& D. A. Booth, unpublished results), as after composite or ordinary meals in man (Johansson, 1973; Malagelada, 1977). However, there is often a short initial burst of absorption and always an eventual slowing when the stomach is nearly empty. These non-linearities may be crucial to the control of meal sizes and meal-to-meal intervals. However, no consequent transient increase shortly after ad lib. access to a meal in the rates of cerebral uptake and conversion of glucose to glutamate and lactate was consistently detected by comparisons of specific activities 5 min after subcutaneous injection of labelled glucose nor was any transient localized to ventral diencephalon (J. C. Newman \& D. A. Booth, unpublished results). The $30 \mathrm{~min}$ or $45 \mathrm{~min}$ period of uptake for the 2-DG method of estimating glucose uptake (Sokoloff, Reivich, Kennedy, Des Rosiers, Patlak, Pettigrew, Sakurada \& Shinohara, 1977) may make it even more unsuited to this purpose. Furthermore, 2-DG uptake is supposed to relate to 'functional activity' (Sokoloff, 1977), which seems to mean increased neuronal discharge rates, although glucose consumption could be increased by metabolic effects of hyperpolarizing neurotransmitters. In contrast, glucose uptake and utilization by a satiety detector or glucose-sensitive neural tissue should be 'pushed' by supply, not 'pulled' by activity. This property is illustrated by the hyperpolarization and decreased discharge rate caused by metabolism of locally- 
administered glucose shown by neurones concentrated in some parts of hypothalamus (Oomura, 1976).

\section{Energy nutrition and neurotransmitters}

5-HT. The $5-\mathrm{HT}$ concentration in brain is increased by a carbohydrate meal, via effects on tryptophan uptake (Fernstrom \& Wurtman, 1971). However, although carbohydrate is the major source of energy in many diets, a relationship between brain 5-HT and energy intake has not been found (Ashley \& Anderson, 1975). A definite role for brain $5-\mathrm{HT}$ in control of normal feeding, perhaps in satiety, remains to be substantiated (Blundell, 1977). If the action of fenfluramine on appetite and body-weight depends on $5-\mathrm{HT}$, the role of peripheral $5-\mathrm{HT}$ must be considered. Most $5^{-\mathrm{HT}}$ lies in the gut and varies with feeding (Biggio, Piccardi, Porceddu \& Gessa, 1977). Fenfluramine slows gastric emptying (Page, Morville \& Corkey, 1978), which can have metabolic and behavioural consequences (Booth, 1978 ) in addition to any primary metabolic action of the drug (Petrie, Mowat, Bewsher \& Stowers, I975).

4-Aminobutyrate (GABA) and glutamate. GABA and perhaps glutamate could link glucose metabolism to synaptic transmission, compartmentation permitting. In rat $\mathrm{VMH}, \mathrm{GABA}$ and glutamate label from $\left[\mathrm{U}-{ }^{14} \mathrm{C}\right]$ glucose increases during feeding (Meeker, McCaleb \& Myers, 1977). Injection of metabolic inhibitors or GABA blockers increases food intake (Meeker \& Panksepp, 1977). VMH glycine or alanine injection suppresses feeding (Panksepp, 1972).

Dopamine (DA). DA depletion disrupts feeding (Ungerstedt, 197I), especially if noradrenaline (NA) is also depleted (Stricker \& Zigmond, 1976). DA release also depresses food intake, it appears from the action of amphetamine (Barrett, 1978). Thus, an optimum rate of DA release may be needed for the sensorimotor coordination and reactivity required for feeding, among other behaviours (Heffner, Zigmond \& Stricker, 1977). Analogously, the clinical actions of fenfluramine and amphetamine may depend on sub-optimal arousal, mood or sensation processing which is not limited to anorexia.

$N A$ and adrenaline $(A)$. These substances may have a specific role in central appetite mechanisms, although until multiple-electrode recordings are made of pharmacologically-identified units during behaviour (Bloom, 1975; Booth, I976) this must remain obscure. Destruction of the ventral noradrenergic bundle causes hyperphagia distinct from the VMH lesion syndrome (Ahlskog, 1974). A usefully more discrete field of adrenergic or noradrenergic terminals may act conversely, to inhibit some aspect of satiety. This field lies close to the magnocellular part of the paraventricular nucleus of the anterior hypothalamus (PVN) and the anterodorsal border of the dorsomedial nucleus (DMN), according to amount eaten in response to injection of rat through suitably fine implants (Routtenberg, 1972; Matthews, Booth \& Stolerman, 1978) and similar experiments (Davis \& Keesey, 197I; Leibowitz, 1976). NA concentrations in these nuclei (approximately $6 \mathrm{ng} / \mathrm{mg}$ ) are the highest in the brain (Versteeg, van der Gugten, de Jong \& Palkovits, 1976), which may improve the chances of defining the function and any metabolic 
peculiarities of this terminal field. DMN and perifornical regions increase in NA content and turnover (also in A content of DMN) during rapid feeding (van der Gugten, 1977). PVN levels suggest chronic NA release in Zucker obese rats (Cruce, Thoa \& Jacobowitz, 1976) which eat large meals frequently even in daylight (Becker \& Grinker, 1977). Simpson \& DiCara (1973) and La Torre (1974) suggested that estradiol may suppress feeding via $D A-\beta$-hydroxylase $(E C$ r.14.2.1) in the same system. Brain NA concentration can be affected by tyrosine uptake (Wurtman, Larin, Mostafapour \& Fernstrom, 1974) which may correlate with energy intake in dietary self-selection (Ashley \& Anderson, 1975).

Intrahypothalamic desmethylimipramine potentiates deprivation-induced food intake (Montgomery, Singer, Purcell, Narbeth \& Bolt, 1969) as well as NA-elicited intake (Booth, 1968b; Slangen \& Miller, 1969), indicating that noradrenergic activity in these terminals may mediate the conditioned de-satiation or persistence in feeding shown by the deprivation-scheduled rat (Le Magnen \& Tallon, I968; Booth, 1972a). At a site where higher doses elicit a meal, a dose of $0.15 \mathrm{nmol}(25$ ng base) or less increases the size of a spontaneous meal (Ritter \& Epstein, 1975). As normal satiation appears to be a learned reaction to a current combination of food cues and bodily cues predictive of forthcoming supply of ready energy (Booth, $1977 b$ ), it may be relevant that NA-elicited feeding seems unusually sensitive to the taste of food (Booth \& Quartermain, 1965).

In contrast to the previously-mentioned medial effects which are sensitive to $\alpha$-adrenergic agonists and antagonists, LH sites with $\beta$ characteristics inhibit feeding (Leibowitz, 1970, 1976), a more specific effect than the interference with deprivation-induced feeding by a wide variety of agents injected into the brain at high doses (Leibowitz, 1976). Margules (1970) conditioned aversion with intrahypothalamic injection of isoproterenol. Booth (1972b) reported both immediate and conditioning effects of intrahypothalamic dibutyryl c-AMP on food intake, dependent on site and dose, although the small immediate effect has not been replicated (Baile, 1974; Herberg \& Stephens, 1976). The normal synaptic action of NA may be long in latency and duration, via adenosine- $3^{\prime}, 5^{\prime}-$ monophosphate (c-AMP) formation (Bloom, 1975). Moreover, NA and other neurotransmitters have many metabolic actions in neural tissue, c-AMP-dependent or not; e.g. affecting protein synthesis (Goldberg, 1972; Reichelt, Edminson \& Kvamme, 1975), enzyme activities such as tyrosine hydroxylase ( $E C$ I.14.3.11) (Roth, Morgenroth \& Salzman, 1975) and lipases (Vyvoda \& Rowe, 1973), maintaining glucose uptake (Schwartz, Sharp, Gunn \& Evarts, 1976) and increasing $\mathrm{O}_{2}$ consumption (Panksepp \& Reilly, I975).

Therefore when measuring diffusion of the injected NA or A (Booth, I $968 b$; Myers, Tytell, Kawa \& Rudy, 1971) it is important to locate sites of intermediary metabolic action as well as of synaptic and vascular action at the moment feeding behaviour is being affected.

\section{APPETITES FOR SALTS AND VITAMINS}

Sodium appetite during $\mathrm{Na}$ depletion is the only specific appetite known to be 
innate. A number of salt and vitamin appetites are known to be based on learned aversion for the deficient diet (Rozin \& Rodgers, 1967) and learned preference for a repleting diet (Zahorik, Maier \& Pies, 1974). No effect of salt or vitamin deficiency causing learning has yet been located, let alone identified biochemically. The behaviourally much studied thiamine appetite (Rozin, 1967) may be a propitious instance in which to seek mediation by neurochemical effects of vitamin deficiency.

\section{Conclusion}

Key experimental questions, which remain to be answered for any neurochemical appetite mechanism, are: (I) does the postulated process vary measurably over a natural range of appetite and satiation; (2) do imposed variations of the process within its natural range affect feeding behaviour specifically and in normal ways?

Such neurochemistry will explain appetite when routing of the physiological inputs to and outputs from the process have also been characterized, with the developmental interactions which created such routing.

\section{REFERENCES}

Ahlskog, J. E. (1974). Brain Res. 82, 211 .

Anderson, G. H. Leprohon, C. \& Coscina, D. V. (1978). In Recent Advances in Obesity Research, vol. 2 [G. A. Bray, editor]. London: Newman.

Ashley, D. V. M. \& Anderson, G. H. (I975). F. Nutr. 105, 1412.

Ashley, D. V. M. \& Anderson, G. N. (1977). Fedn'Proc. Fedn Am. Socs exp. Biol. 36, 4665 Abstr.

Baile, C. A. (1974). Fedn Proc. Fedn Am. Socs exp. Biol. 33, 1166.

Barrett, A. M. (1978). Proc. Nutr. Soc. 37, 193.

Becker, E. E. \& Grinker, J. A. (1977). Physiol. Behav. 18, 685.

Biggio, G., Piccardi, M. P., Porceddu, M. L. \& Gessa, G. L. (1977). Experientia. 33, 745.

Bloom, F. E. (1975). Rev. Physiol. Biochem. Pharmacol. 74, I.

Blundell, J. E. (1977). Int. Y. Obesity. 1, 15.

Booth, D. A. (1968a). F. comp. physiol. Psychol. 65, 13.

Booth, D. A. (1968b). F. Pharmacol. exp. Ther. 160, 3360.

Booth, D. A. (1972a). F. comp. physiol. Psychol. 81, 457.

Booth, D. A. (1972b). Nature, Lond. 237, 222.

Booth, D. A. (1972c). Physiol. Behav. 9, 199.

Booth, D. A. (1974a). Behar. Biol. 12, 31 .

Booth, D. A. (19746). Physiol. Psychol. 2, 344.

Booth, D. A. (1976). In Appetite and Food Intake, p. 4I7 [T. Silverstone, editor]. West Berlin: Dahlem Konferenzen/Abakon Verlagsgesellschaft.

Booth, D. A. (1977a). Psychosom. Med. 39, 76.

Booth, D. A. (1977b). In Food Intake and Chemical Senses, p. 259 [Y. Katsuki, M. Sato, S. Takagi and Y. Oomura, editors]. Tokyo: Tokyo University Press.

Booth, D. A. (editor) (1978). In Hunger Models. London \& New York: Academic Press.

Booth, D. A. \& Jarman, S. P. (1976). F. Physiol., Lond. 259, 501.

Booth, D. A., Lee, M. \& McAleavey, C. (1976). Br. F. Psychol. 67, 137.

Booth, D. A., Lovett, D. \& McSherry, G. M. (1972). F. comp. physiol. Psychol. 78, 485.

Booth, D. A. \& Quartermain, D. (1965). Psychon. Sci. 3, 525.

Booth, D. A. \& Simson, P. C. (1971). Q. Yl exp. Psychol, 23, 135.

Booth, D. A., Stoloff, R. \& Nicholls, J. (1974). Physiol. Psychol. 2, 313.

Booth, D. A., Toates, F. M. \& Platt, S. V. (1976). In Hunger, p.127 [D. Novin, W. Wyrwicka and G. A. Bray, editors]. New York: Raven Press.

Brandes, J. S. (1977). Physiol. Behav. 18, 1095.

Brobeck, J. R. (1946). Physiol. Rez. 26, 54 I.

Bruch, H. (1973). Eating Disorders. New York: Basic Books. 
Cruce, J. A. F., Thoa, N. B. \& Jacobowitz, D. M. (1976). Brain Res. 101, 165.

Das, T. K. \& Waterlow, J. C. (1974). Br. F. Nutr. 32, 353.

Davis, J. R. \& Keesey, R. E. (1971). F. comp. physiol. Psychol. 77, 394.

Debons, A. F., Krimsky, I., From, A. \& Cloutier, R. J. (1969). Am. F. Physiol. 217 , 1114.

Debons, A. F., Krimsky, I., From, A. \& Cloutier, R. J. (1970). Am. F. Physiol. 219 , 1397.

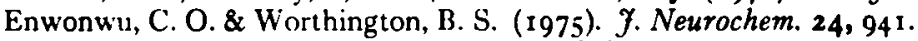

Fernstrom, J. D. \& Wurtman, R. J. (1971). Science, N.Y. 174, 1023.

Fernstrom, J. D. \& Wurtman, R. J. (1974). Scient. Am. 230, 84.

Gaffyn, Z. E. (1972). J. Pathol. 106, 57.

Gilboe, D. D., Andrews, R. L. \& Dardenne, G. (1970). Am. J. Physiol. $219,767$.

Goldberg, M. A. (1972). Brain Res. 39, 17 I.

Grossman, S. P. (1 968). Fedn Proc. Fedn Am. Socs exp. Biol. $27,1349$.

Harper, A. E. (1976). In Hunger, p. 103 [D. Novin, W. Wyrwicka and G. A. Bray, editors]. New York: Raven Press.

Heffner, T. G., Zigmond, M. J. \& Stricker, E. M. (1977). 7. Pharmac. exp. Ther. 201, 386.

Herberg, I. J. \& Stephens, D. N. (1976). Pharmac. Biochem. Behav. 4, 107.

Hogan, J. A. (1973). F. comp. physiol. Psychol. 83, 367.

Inoue, S., Bray, G. A. \& Mullen, Y. S. (1977). Nature, Lond. 266, 742.

Johansson, C. (1973). Scand. $\mathcal{F}$. Gastroent. 8, 533 .

Konorski, J. (1967). Integratice Actirity of the Brain. Chicago: University of Chicago Press.

La Torre, R. A. (1974). Biol. Psychiat. 8, 337.

Leibowitz, S. F. (1970). Proc. Natn. Acad. Sci. U.S.A. 67, 1063.

Ieibowitz, S. F. (1976). In Hunger, p. I [D. Novin, W. Wyrwicka and G. A. Bray, editors]. New York: Raven Press.

Le Magnen, J. \& Tallon, S. (1968). F. Physiol., Paris 58, 143.

Leshner, A. I., Siegel, H. I. \& Collier, G. (1972). Physiol. Behar. 8, 151.

Leung, P. M. B. \& Rogers, Q. R. (1969). Life Sci. 8, 1.

Leung, P. M. B. \& Rogers, Q. R. (1973). Physiol. Behav. $11,221$.

Leung, P. M. B., Rogers, Q. R. \& Harper, A. E. (1 g68). Y. Nutr. 95, 483.

Lutz, J., Tews, J. K. \& Harper, A. E. (1975). Am. F. Physiol. 229, 229.

Malagelada, J. R. (1977). Gastroenterology. 72, 1264.

Margolis, F. L. (1974). Science, N.Y. 184, 909.

Margules, D. L. (1970). 7. comp. physiol. Psychol. 73, 13.

Matthews, J., Booth, D. A. \& Stolerman, I. P. (1 978), Brain. Res. 14I, 119.

Meeker, R. B., McCaleb, M. L. \& Myers, R. D. (1977). Proc. XI int. Conf. Physiol. Fd Fluid Intake. p. 99.

Meeker, R. B. \& Panksepp, J. (1977). Proc. XI int. Conf. Physiol. Fd Fluid Intake. p. 100.

Miller, N. E. (1965). Science, N.Y. 148, 328.

Montgomery, R. B., Singer, G., Purcell, A. T., Narbeth, J. \& Bolt, A. G. (1969). Nature, Lond. 223,1278 .

Musten, B., Peace, D. \& Anderson, G. H. (1974). Y. Nutr. 104, $5^{63}$.

Myers, R. D. (1974). Handhook of Drug and Chemical Stimulation of the Brain. New York: Van Nostrand Reinhold.

Myers, R. D., Tytell, M., Kawa, A. \& Rudy, T. (1971). Physiol. Behav. 7, 743.

Nicoaiddis, S., Monique, P. \& Polonowski, J. (1974). C. R. Acad. Sci., Paris 278, 1 393.

Niijima, A. (1969). Ann. N.Y. Acad. Sci. 1 57, 690.

Noda, K. (1975). F. Nutr. 105, 508.

Novin, D., VanderWeele, D. \& Rezek, M. (1973). Science, N.Y. $181,858$.

Oomura, Y. (1976). In Hunger, p. 145 [D. Novin, W. Wyrwicka \& G. A. Bray, editors]. New York: Raven Press.

Page, M. G., Morville, M. R. \& Corkey, B. E. (1978). In Recent Advances in Obesity Research, vol. 2. [G. A. Bray, editor]. London: Newman.

Panksepp, J. (1971). Physiol. Behar: 7, 381 .

Panksepp, J. (1972). Am. F. Physiol. 223, 396.

Panksepp, J. (1975). Pharmac. Biochem. Behav. 3, Suppl. 1, 107.

Panksepp, J. \& Booth, D. A. (1973). Nature, Lond. 233, 341 .

Panksepp, J. \& Nance, D. M. (1972). Physiol. Behav. 9, 447.

Panksepp, J. \& Pilcher, C. W. T. (1973). Experientia 29, 793.

Panksepp, J. \& Reilly, P. (1975). Brain Res. 94, 133 .

Peng, Y. \& Harper, A. E. (1970). Fedn Proc. Fedn Am. Socs exp. Biol. 29, 427 Abstr. 
Peng, Y., Tews, J. \& Harper, A. E. (1972). Am. f. Physiol. 222, 314.

Petrie, J. C., Mowat, J. A., Bewsher, P. D. \& Stowers, J. M. (1975). Postgrad. med. J. 5r, Suppl. 1, 139.

Pilcher, C. W. T., Jarman, S. P. \& Booth, D. A. (1974). J. comp. physiol. Psychol. 87, 56.

Powley, T. L. (1977). Psychol. Rez. 84, 89.

Quinn, M. R. \& Fisher, H. (1977). 7. Neurochem. 29, 717.

Rahin, B. M. (1972). Brain Res. 43, 317.

Rafaelson, O. J. (196I). F. Neurochem. 7, 45.

Reichelt, K. L., Edminson, P. D. \& Kvamme, E. (1975). F. Neurochem. 26, 8 I r.

Reisbick, S. H. (1 973). f. comp. physiol. Psychol. 85, 427.

Ritter, R. C. \& Epstein, A. N. (1975). Proc. Natn Acad. Sci. U.S.A. 72, 3740.

Roberts, S. (1974). Ciba Fdn Symp. no. 22. p. 299.

Roehner, F., Dufour, A. C., Karakash, C., Le Marchand, Y., Ruf, K. B. \& Jeanrenaud, B. (1977). Diabetologia. 13, 239.

Roth, R. H., Morgenroth, V. H. \& Salzman, P. M. (1975). Naumyn Schmiederbergs Arch. Pharmakol. 289, 327.

Routtenberg, A. (1972). Behaz. Biol. 7,601.

Rozin, P. (1967). In Handhook of Physiology, Alimentary Canal, vol. I, p. 4II. Washington: American Physiological Society.

Rozin, P. \& Rodgers, W. (1967). F. comp. physiol. Psychol. 63, 429.

Russek, M. (1963). Nature, Lond. 197, 79 .

Russek, M. (1970). Neurosci. Res. 4, 213.

Russell, P. J. D. \& Mogenson, G. J. (1975). Am. F. Physiol. 229, ror4.

Schoenfeld, T. A. \& Hamilton, L. W. (1976). F. comp. Physiol. Psychol. go, 1092.

Schwartz, W. J., Sharp, F. R., Gunn, R. H. \& Evarts, E. V. (1976). Nature, Lond. 261, 155.

Sclafani, A. (1971). J. comp. physiol. Psychol. 77, 70.

Simpson, C. W. \& DiCara, L. V. (1973). Pharmac. Biochem. Behav. 1, 413.

Simson, P. C. \& Booth, D. A. (1 973). Physiol. Behav. 11, 801.

Simson, P. C. \& Booth, D. A. (1974a). Br. F. Nutr. 31, 285.

Simson, P. C. \& Booth, D. A. (1974b). Pharmac. Biochem. Behav. 2, 48 r.

Slangen, J. L. \& Miller, N. E. (1969). Physiol. Behav. 4, 543.

Smith, C. V. J. (1972). Physiol. Behar. 9, 391.

Sokoloff, L. (1977). Y. Neurochem. 29, 13.

Sokoloff, L., Reivich, M., Kennedy, C., Des Rosiers, M. H., Patlak, C. S., Pettigrew, K. D., Sakurada, O. \& Shinohara, M. (1977). F. Neurochem. 28, 897.

Stricker, E. M., Rowland, N., Saller, C. F. \& Friedman, M. I. (1977). Science, N.Y. 196, 79.

Stricker, E. M. \& Zigmond, M. J. (1976). In Progress in Psychobiology and Physiological Psychology, p. 121 [J. M. Sprague \& A. N. Epstein, editors]. New York: Academic Press.

Strubbe, J. H. (1973). Insulin, glucose and feeding behaviour in the rat: a reappraisal of the glucostatic theory. PhD Thesis, Lniversity of Groningen.

Szabo, O. \& Szabo, A. J. (1972). Am. J. Physiol. 223, 1349.

Tanikawa, K. (1968). In Ultrastructural Aspects of the Liver and its Disorders, p. 50. Tokyo: Igaku Shoin.

Tyfield, L. A. \& Bolton, J. B. (1976). f. Neurochem. 26, 101.

Ungerstedt, U. (1971). Acta Physiol. Scand. Suppl. 367,69.

Van der Gugten, J. ( 1977 ). Neurochemical identification of hypothalamic catecholamine neuron systems involved in feeding behaviour of the rat. $\mathrm{PhD}$ thesis, University of Utrecht.

Versteeg, D. H. G., Van der Gugten, J., de Jong, W. \& Palkovits, M. (1976). Brain Res. 113, 563.

Vyvoda, D. S. \& Rowe, C. E. (1973). Biochem. F. 132, 233.

Wayner, M. J., Ono, T., DeYoung, A. \& Barone, F. C. (r975). Pharmac. Biochem. Behav. 3, Suppl. I, 85 .

Wurtman, R. J., Larin, F., Mostatapour, S. \& Fernstrom, J. D. (1974). Science, N.Y. 185, 184.

Wurtman, J. J. \& Wurtman, R. J. (1977). Fedn Proc. Fedn Am. Socs exp. Biol. 36, I 132.

Zahler, L. P. \& Harper, A. E. (1972). F. comp. physiol. Psychol. 81, 155.

Zahorik, D. M., Maier, S. F. \& Pies, R. W. (1974). F. comp. physiol. Psychol. 87, 1083 . 